\title{
Decrease in failure load of inclined driven piles by using Allpile program
}

\author{
Ahmed Al-Gharbawi ${ }^{1 *}$ \\ ${ }^{1}$ Building and Construction Engineering Department, University of Technology, Baghdad, Iraq
}

\begin{abstract}
One of the problems in construction piles in field is driven inclined which maybe become by error during putting pile or driven. This type of problem in construction is difficult to determine bearing capacity. In this research, studying the determination of bearing capacity of inclined pile in deferent angles and different types of soil as well as deferent types of piles shapes by using AllPile program. The results demonstrate that the reduction in bearing capacity of $30^{\circ}$ inclined pile less than $20 \%$ from the non inclined pile.
\end{abstract}

\section{Introduction}

The load at the pile head gradually increases from a very small value to the limit load $\left(\mathrm{Q}_{\mathrm{L}}\right)$ required for pile to penetrate into the ground at a constant rate (Salgado, $2006)^{[1]}$. Sometimes piles are driven or constructed inclined in civil structures by mistake or for some reason. Many codes and standards do not prefer to use inclined pile in structures especially in seismic regions.

(Li and Luo, 2011) ${ }^{[2]}$ studied the development of pile foundation by using group of piles constructed inclined with a center pile constructed in the different angles of inclination. The result showed that the optimum inclination angle for the center pile is located between 8 $12^{\circ}$.

A significant amount of work (Mylonakis et al. 1997) ${ }^{[3]}$ has been carried out in reliable prediction of the response of structures with vertical piles exposed to seismic excitations as vertical piles are undoubtedly a popular choice for a wide range of structures. Inclined piles (sometimes named 'batter piles' or 'raked piles'), on the other hand, are particularly desired for structures demanding substantial lateral stiffness and these piles were used in hydraulic structures, towers, and bridges. The major problem of inclined piles are the mechanism of transfer the vertical load from the structure through the piles cap to piles then the bed of the soil, so the bearing capacity is reduced. In recent years, evidence has been accumulating that inclined piles may, in certain case, be beneficial rather than detrimental both for the structure they support and the piles themselves, (Gazetas and Mylonakis, 1998) ${ }^{[4]}$. Studies by (Sadek and Shahrour, 2004) ${ }^{[5]}$ showed that supporting by using inclination piles improved some sided of the seismic reaction of the structures.

\section{AllPile program}

The program AllPile for Windows analyzes pile load capacity efficiently and accurately. AllPile can handle all types of piles: drilled shaft, driven pile, auger-cast pile, steel pipe pile, H-pile, timber pile, tapered pile, bell pile, shallow foundation, etc. You can define new pile types and input customized parameters based on local practices and experience. The program is capable of performing the following calculations:

- Lateral capacity and deflection.

- Vertical capacity and settlement.

- Group vertical and lateral analysis.

- FHWA SHAFT program.

- Static and cyclic conditions.

- Negative and zero friction.

- Shallow footing.

- Tower foundation.

The main AllPile window is shown in Figure (1). And the AllPile operations can be divided into three main steps as shown in Figure (2) (Allpile manual, 2014) $)^{[6]}$. 




Fig. 1. AllPile window.

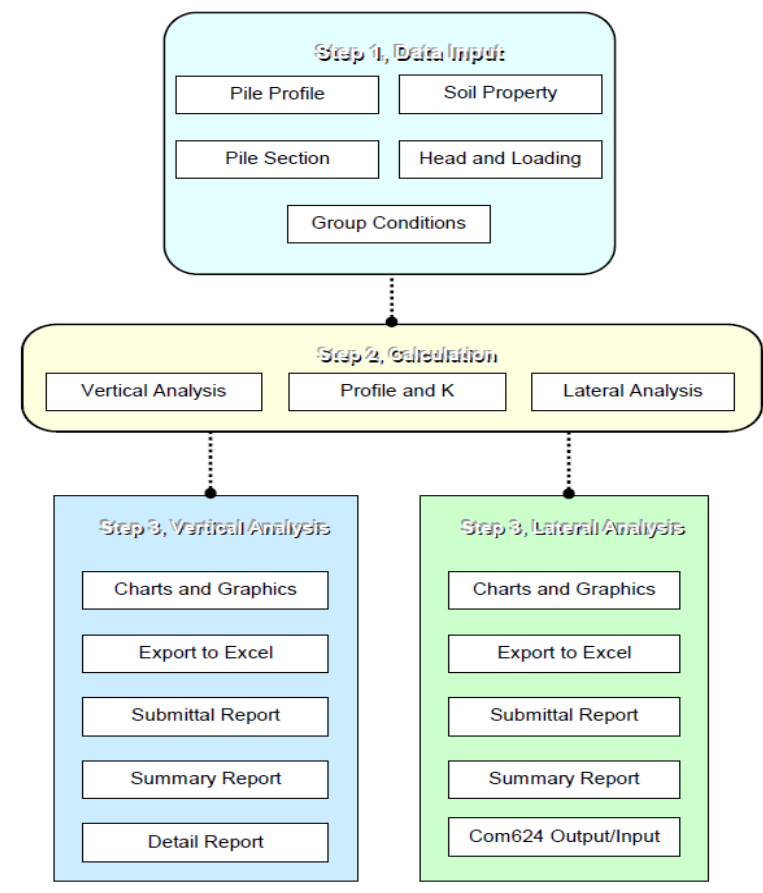

Fig, 2. Program Flowchart.

\section{Properties of soil used}

\subsection{Soil}

In this research two types of soil were used (Sand and Clay). In sand soil two states dry and fully saturated and fully saturated clayey soil were used. The properties of soil used is shown in Table (1).

Table 1. Soil properties.

\begin{tabular}{cc}
\hline \hline Soil Type & Properties \\
\hline \multirow{2}{*}{ Soft Clay } & Undraind Shear Strength $(\mathrm{cu})=25 \mathrm{kN} / \mathrm{m}^{2}$ \\
& Angle of Internal Friction $(\varnothing)=0^{\circ}$ \\
& Submerged Unit Weight $(\gamma)=8 \mathrm{kN} / \mathrm{m}^{3}$ \\
\hline \multirow{2}{*}{ Sand } & Cohesion $(\mathrm{c})=0 \mathrm{kN} / \mathrm{m}^{2}$ \\
& Angle of Internal friction $(\varnothing)=33^{\circ}$ \\
& Relative Density $($ Dr $)=33 \%$ \\
& Dry Unit Weight $(\gamma)=18.1 \mathrm{kN} / \mathrm{m}^{3}$ \\
\hline \hline
\end{tabular}

\section{Submerged Unit Weight $(\gamma)=8.5 \mathrm{kN} / \mathrm{m}^{3}$}

\subsection{Pile}

In this research four types of piles were used (square driven concrete, circle driven concrete, steel driven, and hollow steel driven pile) each of them had length (h) 12 $\mathrm{m}$ and diameter (or width) (d) $30 \mathrm{~cm}$. The properties of piles is shown in Table (2). The sketch of pile in the soil with different angles of inclination are shown in Figure (3).

Table 2. Pile properties

\begin{tabular}{cc}
\hline \hline Pile Type & Properties \\
\hline Concrete & $\begin{array}{c}\text { Moment of Inertia (I) }=67500 \mathrm{~cm}^{4} \text { for square Piles } \\
\text { Moment of Inertia }(\mathrm{I})=39760.8 \mathrm{~cm}^{4} \text { for circular } \\
\text { Piles }\end{array}$ \\
& Modulus of Elasticity (E) $=20683 \mathrm{MPa}$ \\
\hline \multirow{2}{*}{ Steel } & Moment of Inertia $(\mathrm{I})=39760.8 \mathrm{~cm}^{4}$ \\
& Modulus of Elasticity (E) $=199938 \mathrm{MPa}$ \\
& Yield Modulus (Fy) $=310 \mathrm{MPa}$ \\
\hline \hline
\end{tabular}

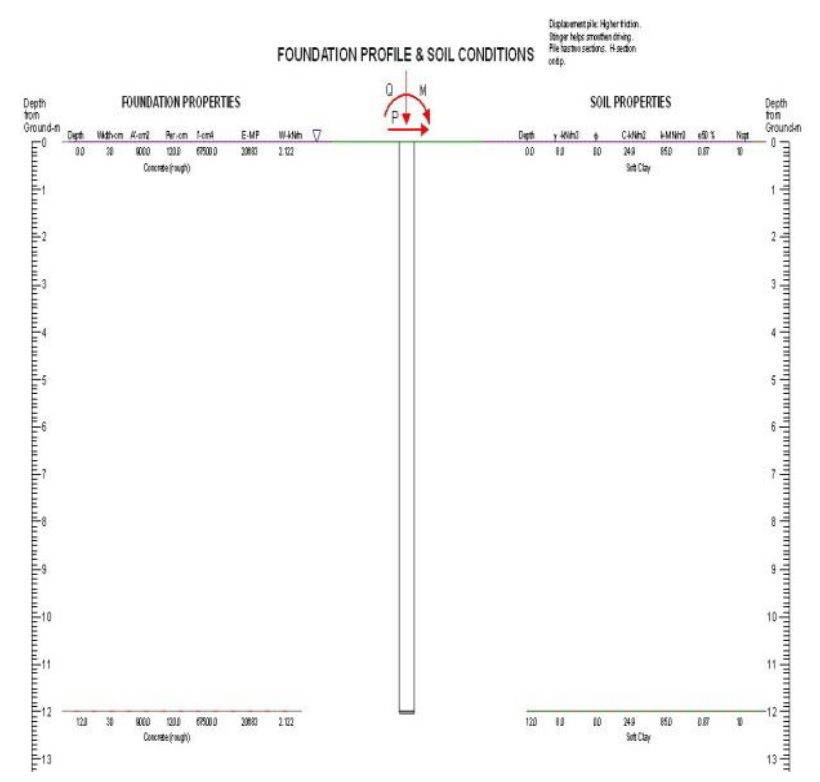

(a) 


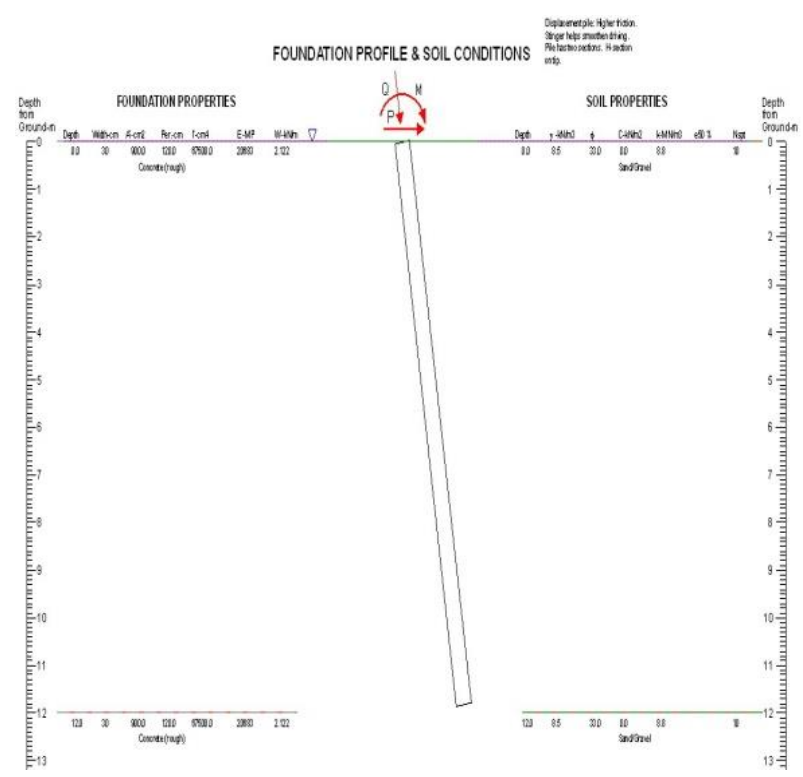

(b)

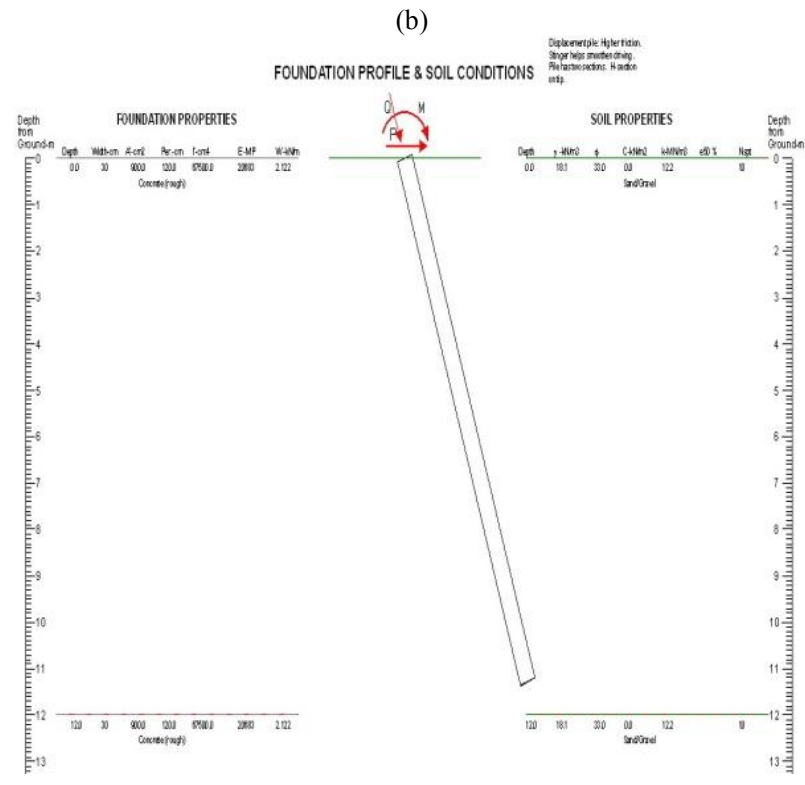

(c)

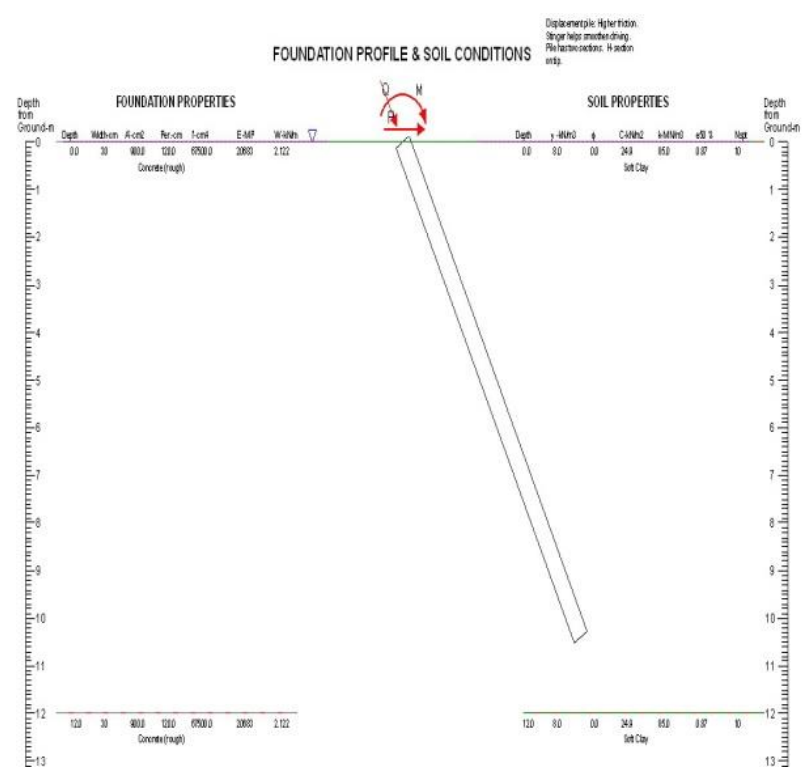

(d)
Fig. 3. The sketch of pile in the soil with different angles of inclination (a) $0^{\circ}$ (b) $10^{\circ}$ (c) $20^{\circ}$ (d) $30^{\circ}$

\section{Presentation of test results}

Failure of model tests is defined as the stress required to cause settlement corresponding to $10 \%$ of the footing diameter (width) depending on the proposal given by (Terzaghi, 1947).

The analysis of results of all model tests regarding the compression load and the corresponding settlement is illustrated in terms of corresponding load (Q) versus settlement (X).

\subsection{Soft clay soil}

\subsubsection{Driven concrete square pile}

4 virtual model tests were performed in this type of piles with inclination $0,10,20$ and $30^{\circ}$, the result demonstrated the decrease in failure load with increase the inclination. Figures (4) and (5) are shown the relation between load and settlement for bearing effect only and friction effect only for pile, respectively. Figure (6) is shown the relation between load and settlement. The loads corresponding $10 \%$ settlement ratio are shown in Table (3).

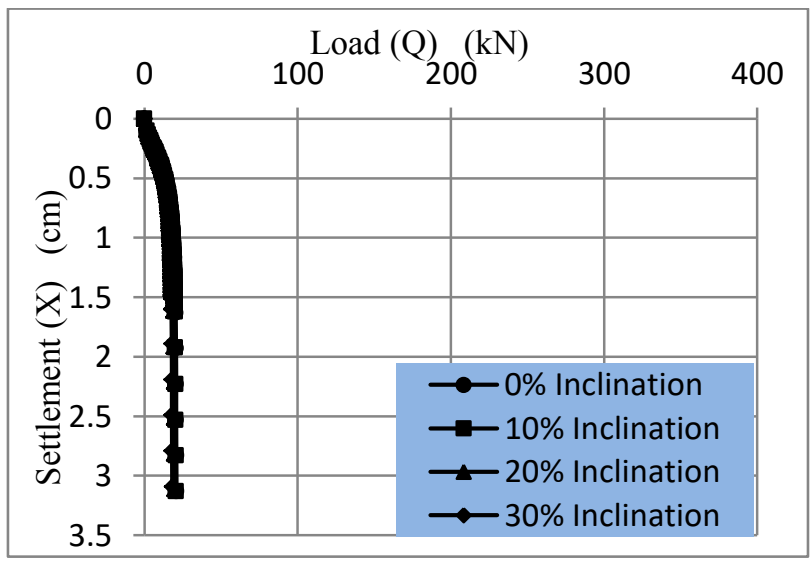

Fig. .4. Load-Settlement curve for a square concrete pile driven in soft clay soil for bearing effect only

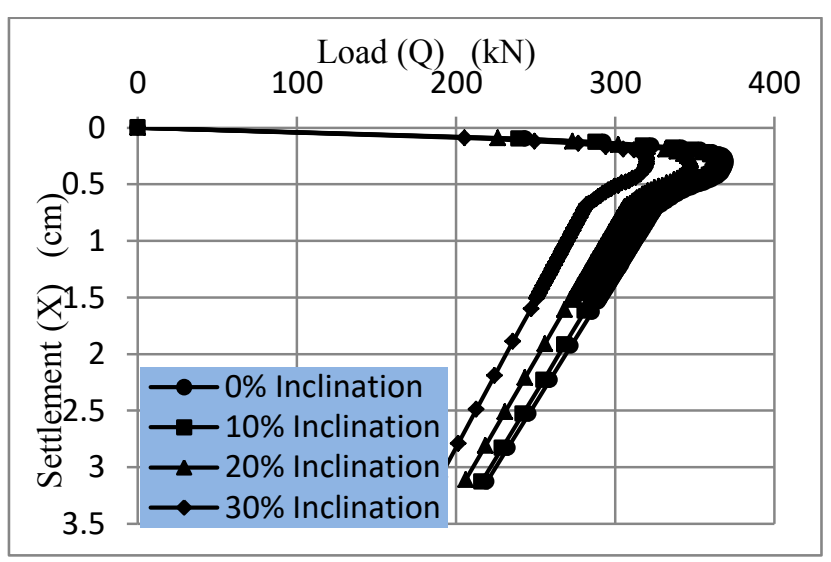


Fig. 5. Load-Settlement curve for a square concrete pile driven in soft clay soil for shaft friction effect only

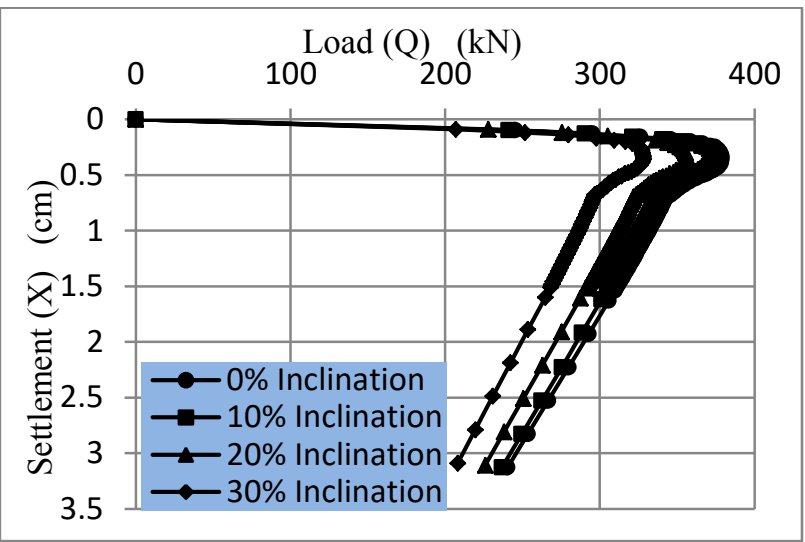

Fig. 6. Load-Settlement curve for a square concrete pile driven in soft clay soil

\subsubsection{Driven concrete circular pile}

4 virtual model tests were performed in this type of piles with inclination $0,10,20$ and $30^{\circ}$. Figures (7) and (8) are shown the relation between load and settlement for bearing effect and friction effect only for pile, respectively. Figure (9) shows the relation between load and settlement. The loads corresponding $10 \%$ settlement ratio are shown in Table (3).

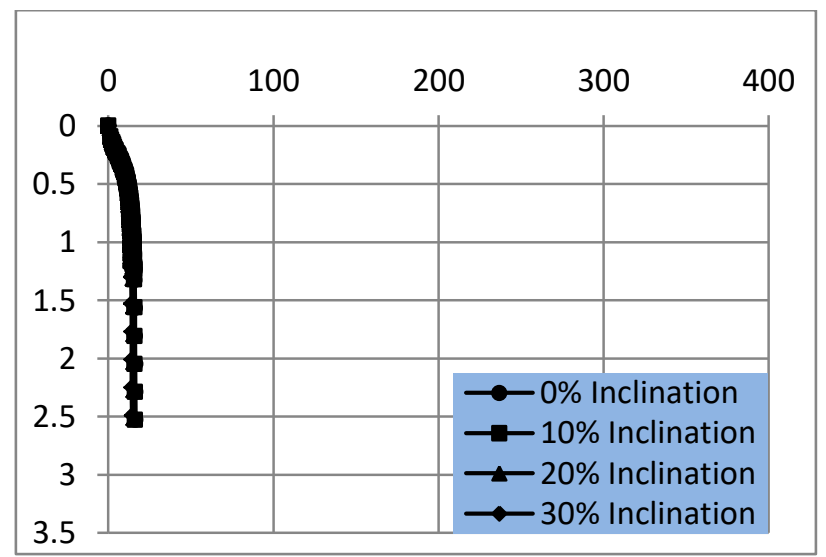

Fig. 7. Load-Settlement curve for a circular concrete pile driven in soft clay soil for bearing effect only

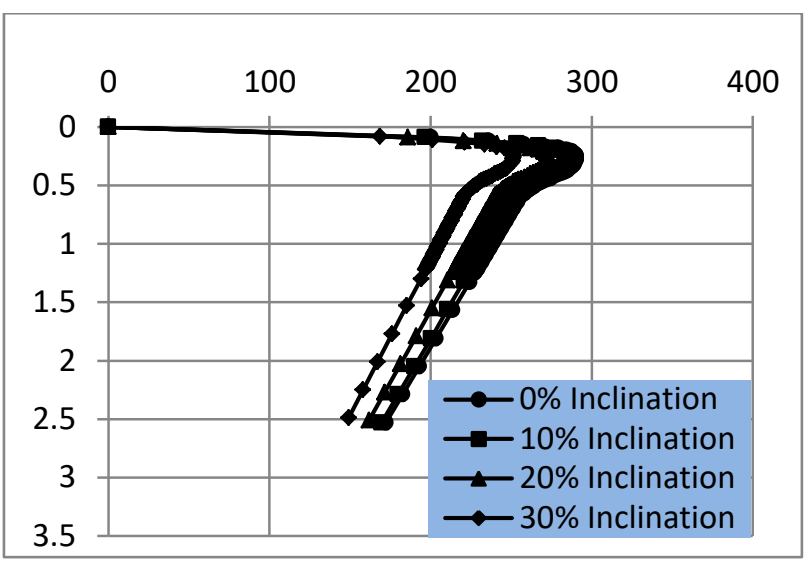

Fig. 8. Load-Settlement curve for a circular concrete pile driven in soft clay soil for shaft friction effect only

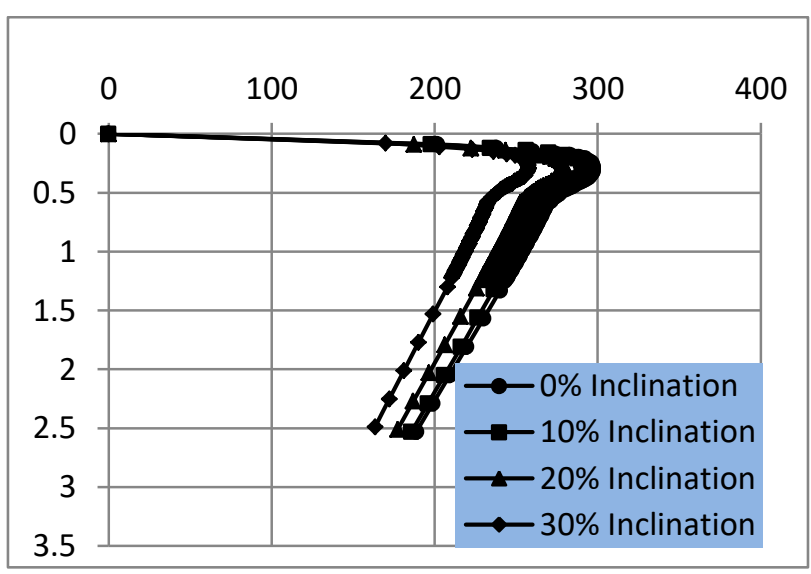

Fig.9. Load-Settlement curve for a circular concrete pile driven in soft clay soil with different angles

\subsubsection{Driven steel circular pile}

4 virtual model tests were performed in this type of piles with inclination $0,10,20$ and $30^{\circ}$. Figures (10) and (11) show the relation between load and settlement for bearing effect and friction effect only for pile, respectively. Figure (12) shows the relation between load and settlement. The loads corresponding $10 \%$ settlement ratio are shown in Table (3).

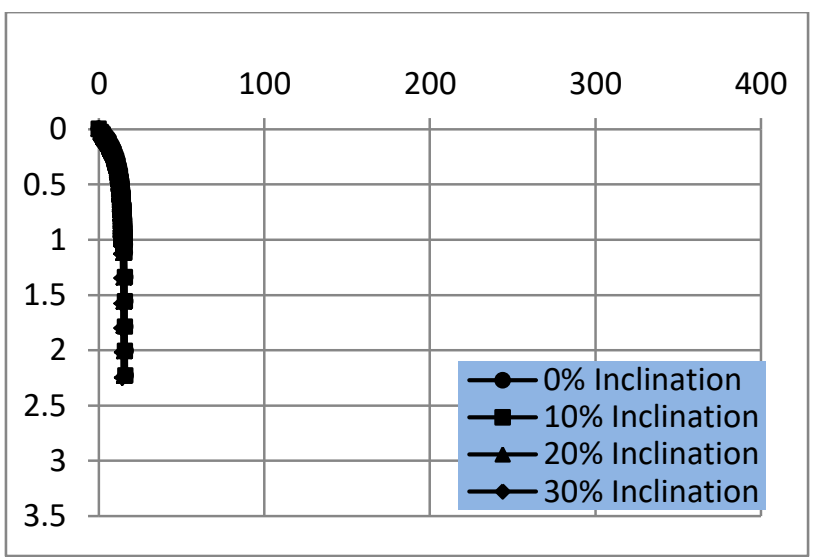


Fig. 10. Load-Settlement curve for a circular steel pile driven in soft clay soil for bearing effect only

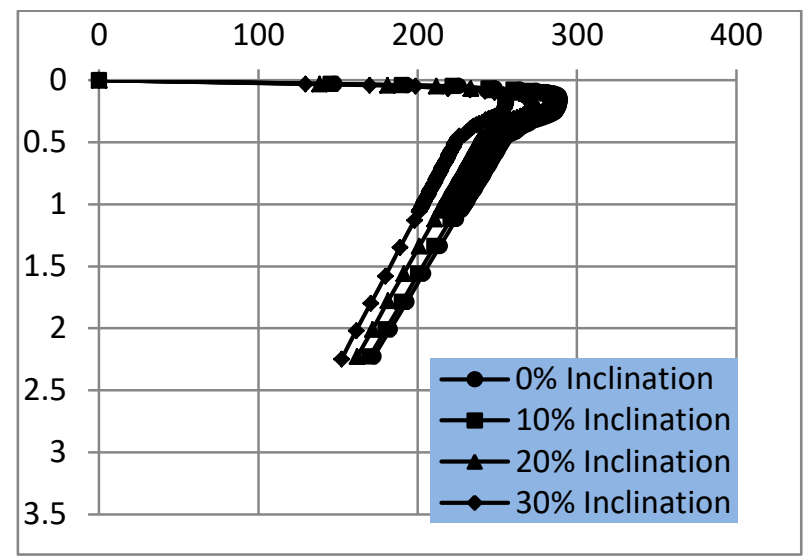

Fig. 11. Load-Settlement curve for a circular steel pile driven in soft clay soil for shaft friction effect only

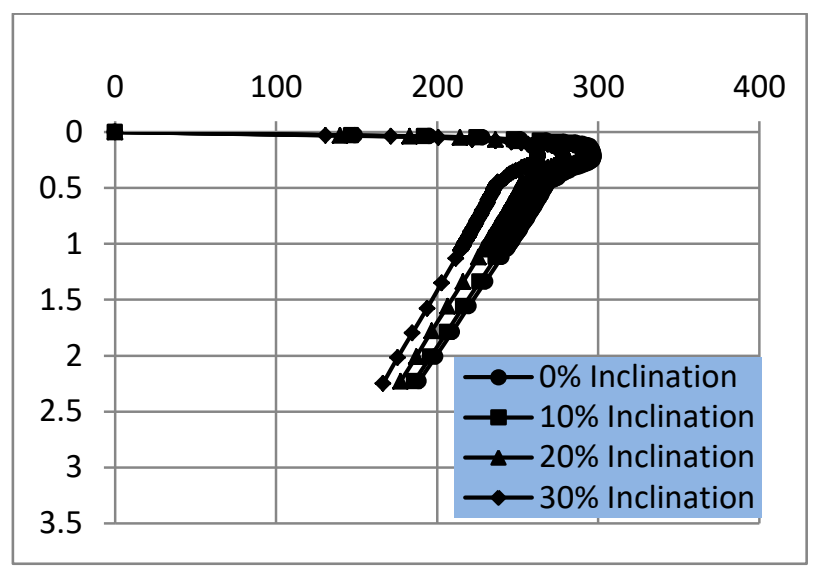

Fig. 12. Load-Settlement curve for a circle steel pile driven in soft clay soil with different angles

\subsubsection{Driven hollow steel circular pile}

4 virtual model tests were performed in this type of piles with inclination $0,10,20$ and $30^{\circ}$. Figures (13) and (14) show the relation between load and settlement for bearing effect and friction effect only for pile, respectively. Figure (15) shows the relation between load and settlement. The loads corresponding $10 \%$ settlement ratio are shown in Table (3).

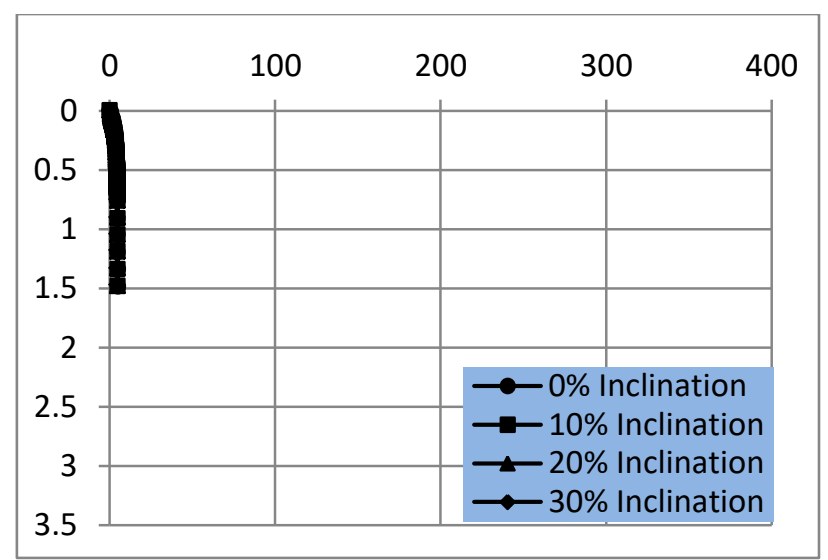

Fig. 13. Load-Settlement curve for a hollow circular steel pile driven in soft clay soil for bearing effect only

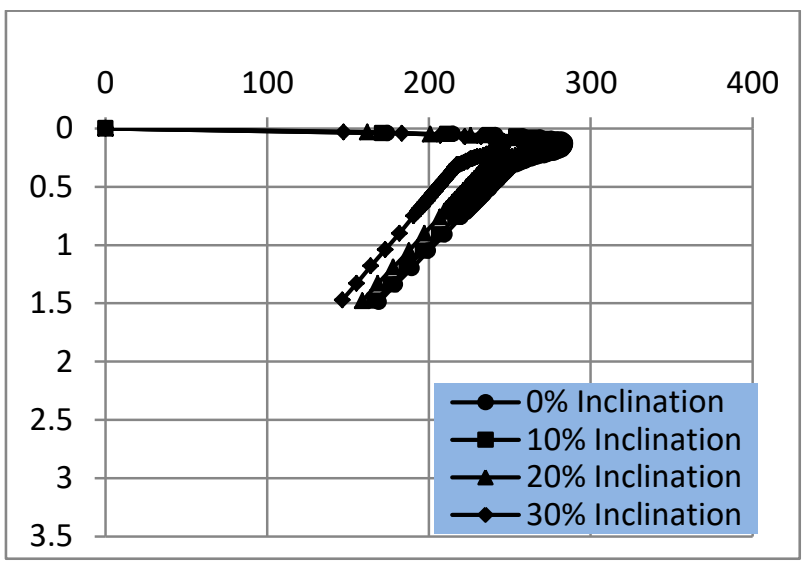

Fig. 14. Load-Settlement curve for a hollow circular steel pile driven in soft clay soil for shaft friction effect only

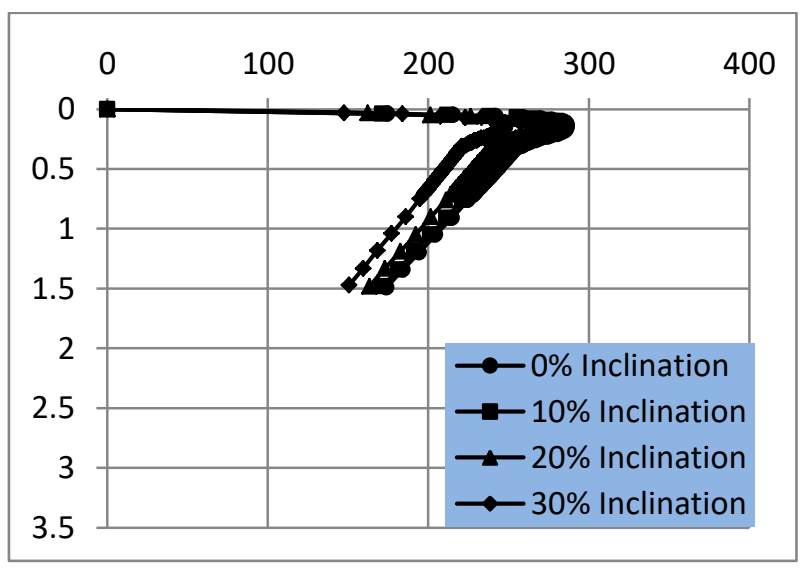

Fig. 15. Load-Settlement curve for a hollow circular steel pile driven in soft clay soil

\subsection{Fully saturated sandy soil}

\subsubsection{Driven concrete square pile}

4 virtual model tests were performed in this type of piles with inclination $0,10,20$ and $30^{\circ}$. Figures (16) and (17) show the relation between load and settlement for bearing effect and friction effect only for pile, respectively. Figure (18) shows the relation between load and settlement. The loads corresponding 10\% settlement ratio are shown in Table (3). 




Fig. 16. Load-Settlement curve for a square concrete pile driven in fully saturated sandy soil for bearing effect only

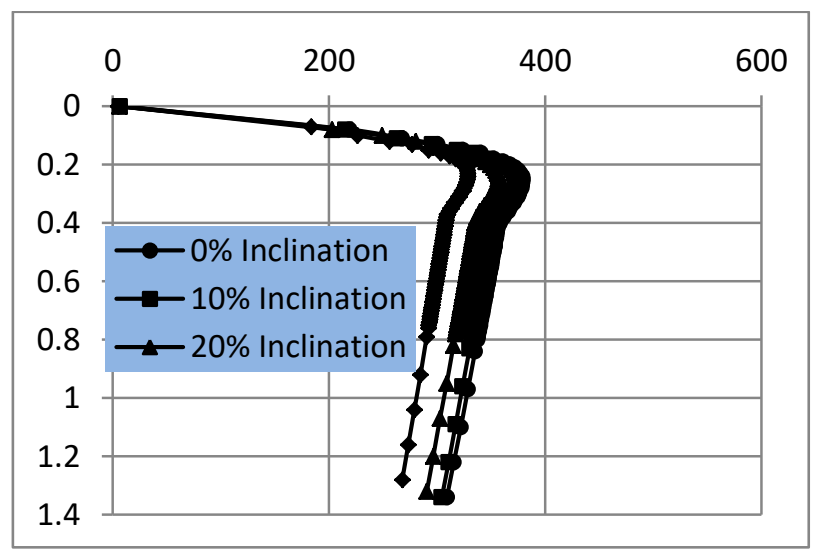

Fig. 17. Load-Settlement curve for a square concrete pile driven in fully saturated sandy soil for shaft friction effect only

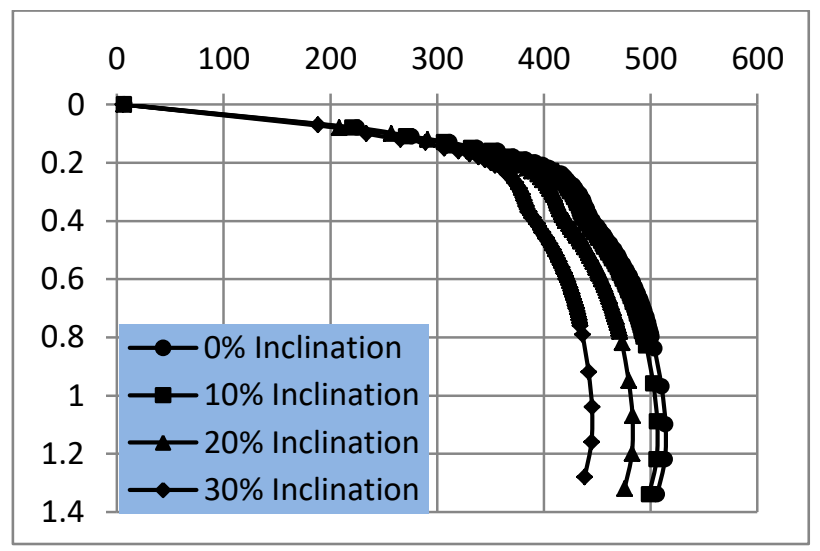

Fig. 18. Load-Settlement curve for a square concrete pile driven in fully saturated sandy soil

\subsubsection{Driven concrete circular pile}

4 virtual model tests were performed in this type of piles with inclination $0,10,20$ and $30^{\circ}$. Figures (19) and (20) show the relation between load and settlement for bearing effect and friction effect only for pile, respectively. Figure (21) shows the relation between load and settlement. The loads corresponding $10 \%$ settlement ratio are shown in Table (3).

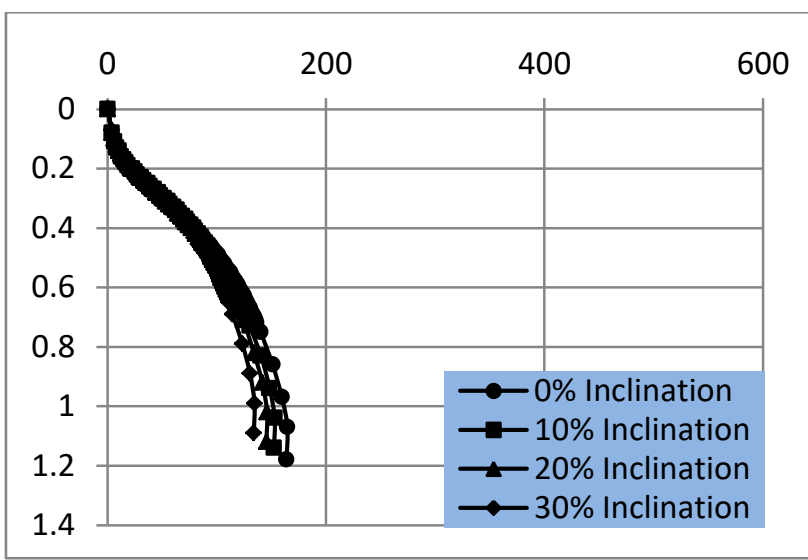

Fig. 19. Load-Settlement curve for a circular concrete pile driven in fully saturated sandy soil for bearing effect only

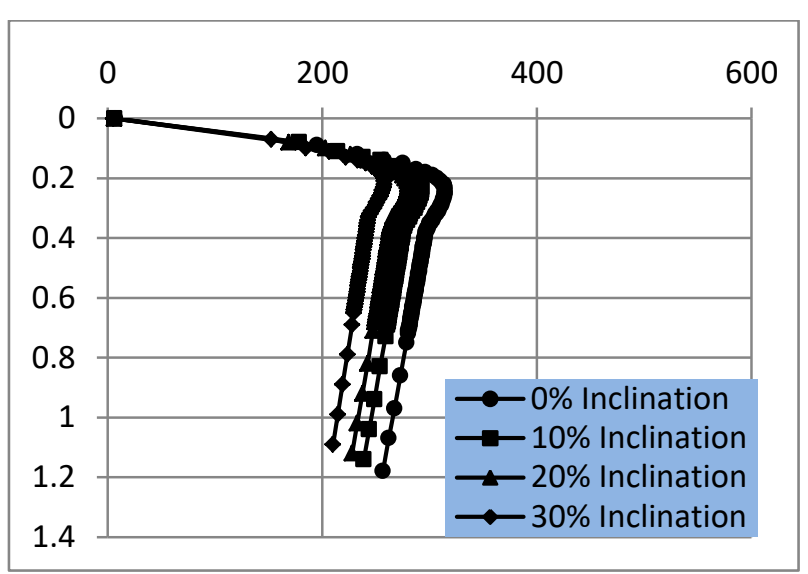

Fig. 20. Load-Settlement curve for a circular concrete pile driven in fully saturated sandy soil for shaft friction effect only

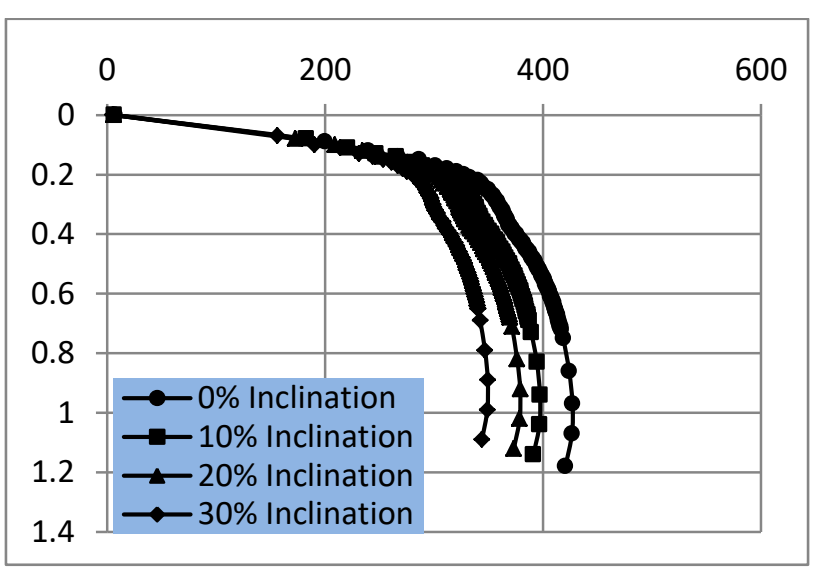

Fig. 21. Load-Settlement curve for a circular concrete pile driven in fully saturated sandy soil

\subsubsection{Driven steel circular pile}

4 virtual model tests were performed in this type of piles with inclination $0,10,20$ and $30^{\circ}$. Figures (22) and (23) show the relation between load and settlement for bearing effect and friction effect only for pile, respectively. Figure (24) shows the relation between load 
and settlement. The loads corresponding 10\% settlement ratio are shown in Table (3).

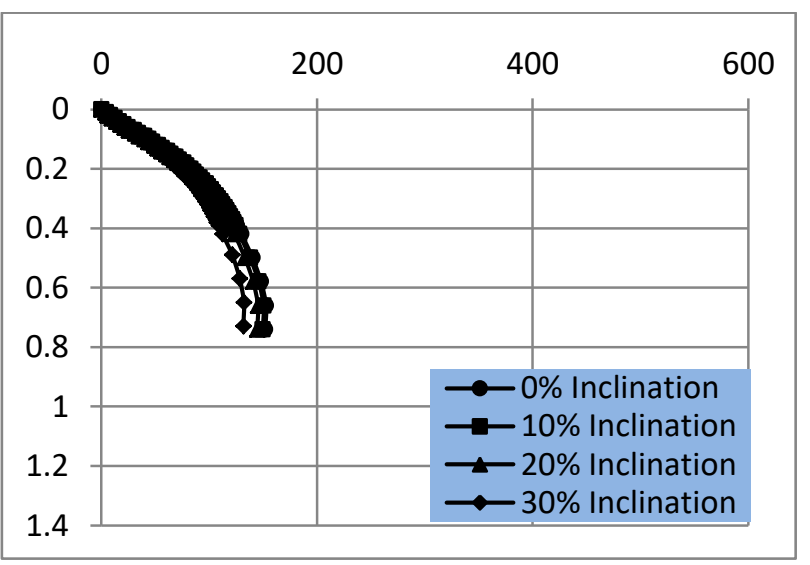

Fig. 22. Load-Settlement curve for a circular steel pile driven in fully saturated sandy soil for bearing effect only

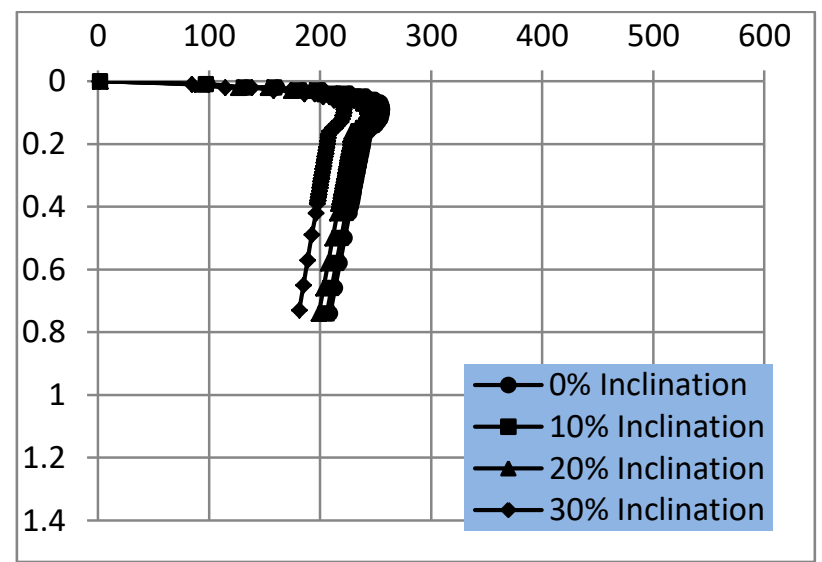

Fig. 23. Load-Settlement curve for a circular steel pile driven in fully saturated sandy soil for shaft friction effect only

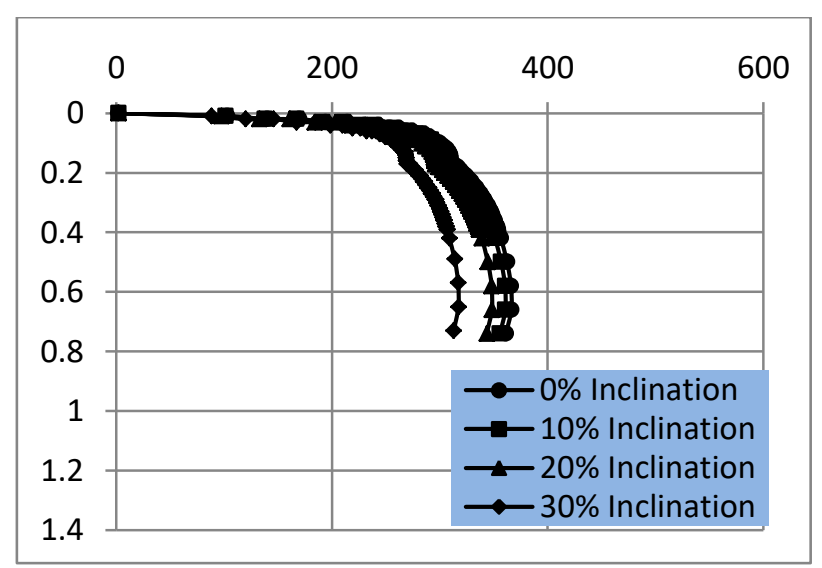

Fig. 24. Load-Settlement curve for a circular steel pile driven in fully saturated sandy soil

\subsubsection{Driven hollow steel circular pile}

4 virtual model tests were performed in this type of piles with inclination $0,10,20$ and $30^{\circ}$. Figures (25) and (26) show the relation between load and settlement for bearing effect and friction effect only for pile, respectively. Figure (27) shows the relation between load and settlement. The loads corresponding $10 \%$ settlement ratio are shown in Table (3).

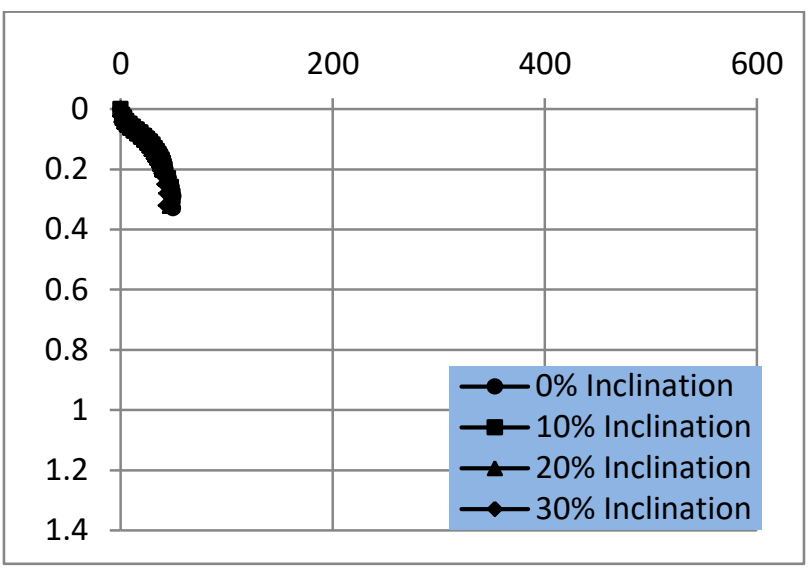

Fig. 25. Load-Settlement curve for a circular hollow steel pile driven in fully saturated sandy soil for bearing effect only

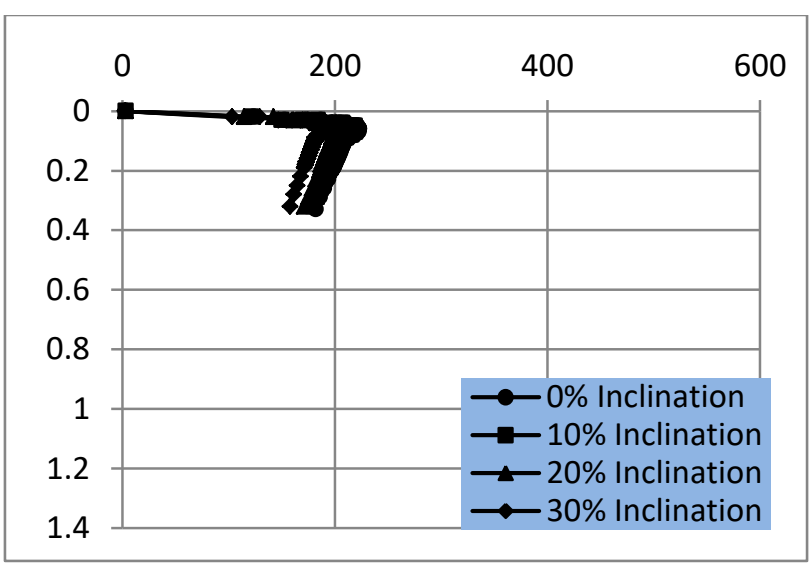

Fig. 26. Load-Settlement curve for a circular hollow steel pile driven in fully saturated sandy soil for shaft friction effect only

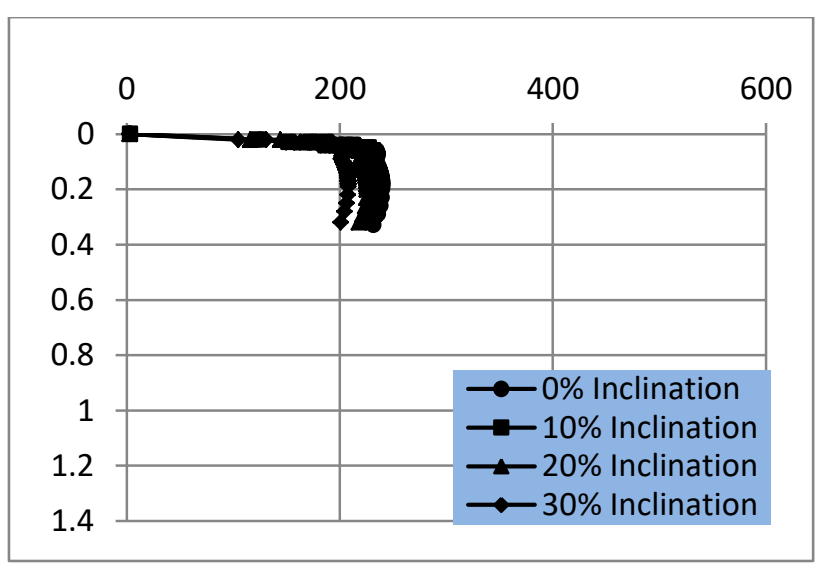

Fig. 27. Load-Settlement curve for a circular hollow steel pile driven in fully saturated sandy soil

\subsection{Dry sandy soil}

\subsubsection{Driven concrete square pile}


4 virtual model tests were performed in this type of piles with inclination $0,10,20$ and $30^{\circ}$. Figures (28) and (29) show the relation between load and settlement for bearing effect and friction effect only for pile, respectively. Figure (30) shows the relation between load and settlement. The loads corresponding $10 \%$ settlement ratio are shown in Table (3).

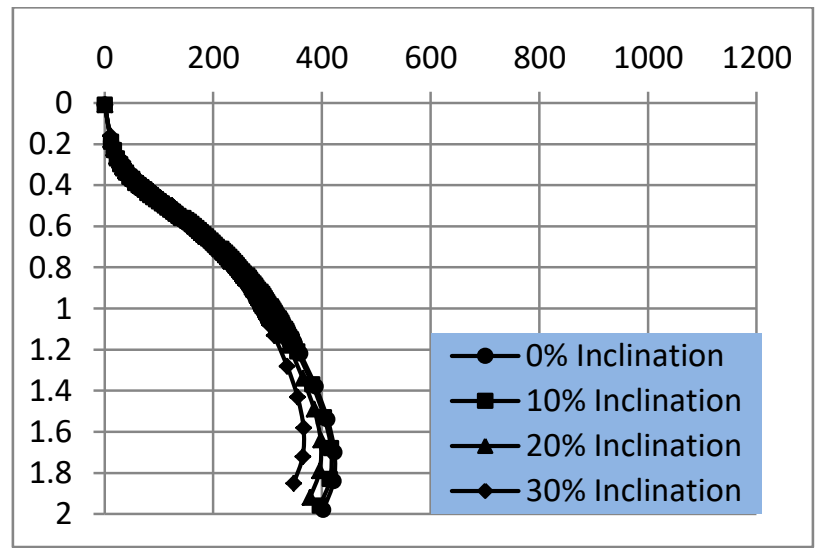

Fig. 28. Load-Settlement curve for a square concrete pile driven in dry sandy soil for bearing effect only

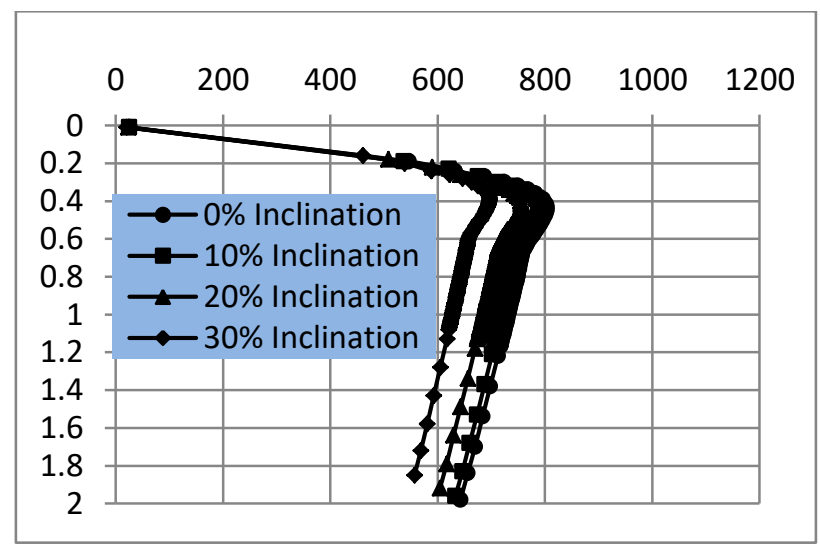

Fig. 29. Load-Settlement curve for a square concrete pile driven in dry sandy soil for shaft friction effect only

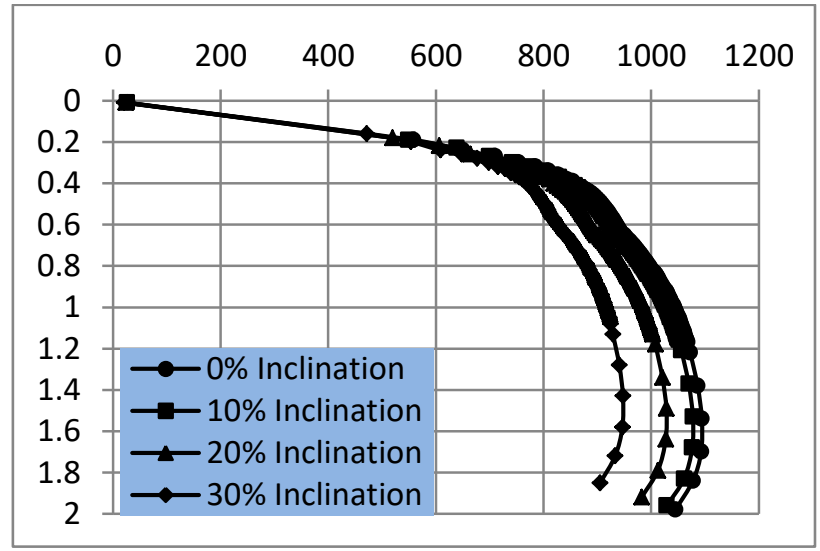

Fig. 30. Load-Settlement curve for a square concrete pile driven in dry sandy soil

\subsubsection{Driven concrete circular pile}

4 virtual model tests were performed in this type of piles with inclination $0,10,20$ and $30^{\circ}$. Figures (31) and (32) show the relation between load and settlement for bearing effect and friction effect only for pile, respectively. Figure (33) shows the relation between load and settlement. The loads corresponding $10 \%$ settlement ratio are shown in Table (3).

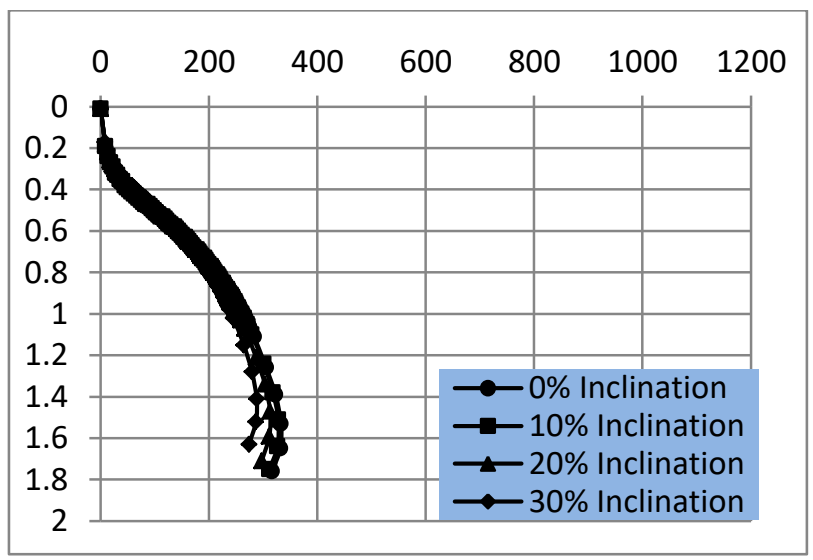

Fig. 31. Load-Settlement curve for a circular concrete pile driven in dry sandy soil for bearing effect only

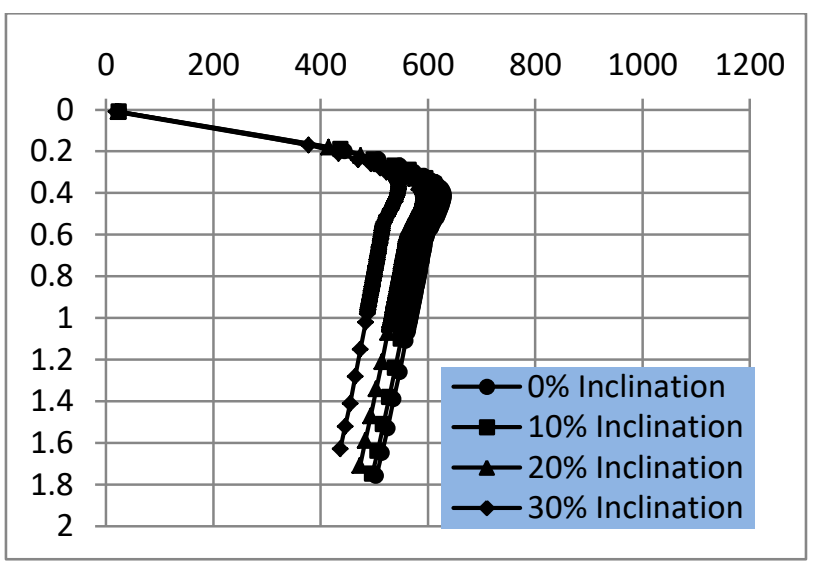

Fig. 32. Load-Settlement curve for a circular concrete pile driven in dry sandy soil for shaft friction effect only

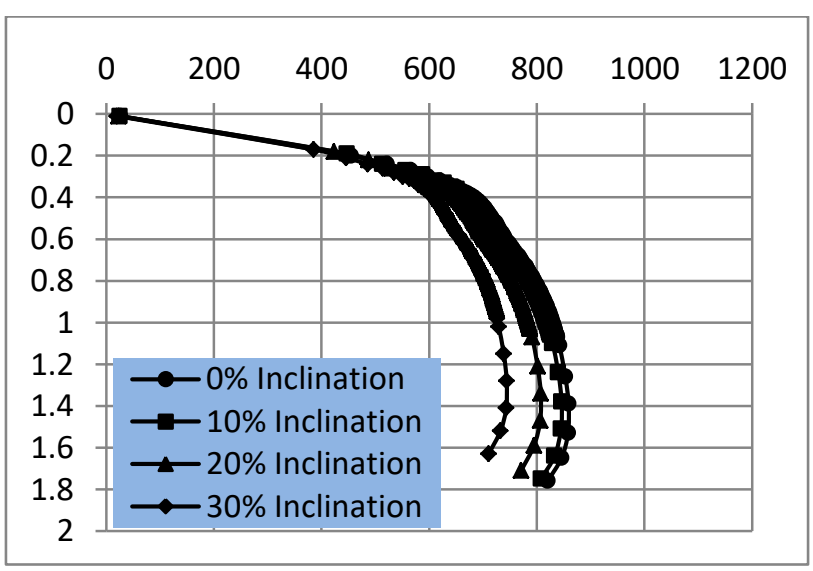

Fig. 33. Load-Settlement curve for a circular concrete pile driven in dry sandy soil 


\subsubsection{Driven steel circular pile}

4 virtual model tests were performed in this type of piles with inclination $0,10,20$ and $30^{\circ}$. Figures (34) and (35) show the relation between load and settlement for bearing effect and friction effect only for pile, respectively. Figure (36) shows the relation between load and settlement. The loads corresponding $10 \%$ settlement ratio are shown in Table (3).

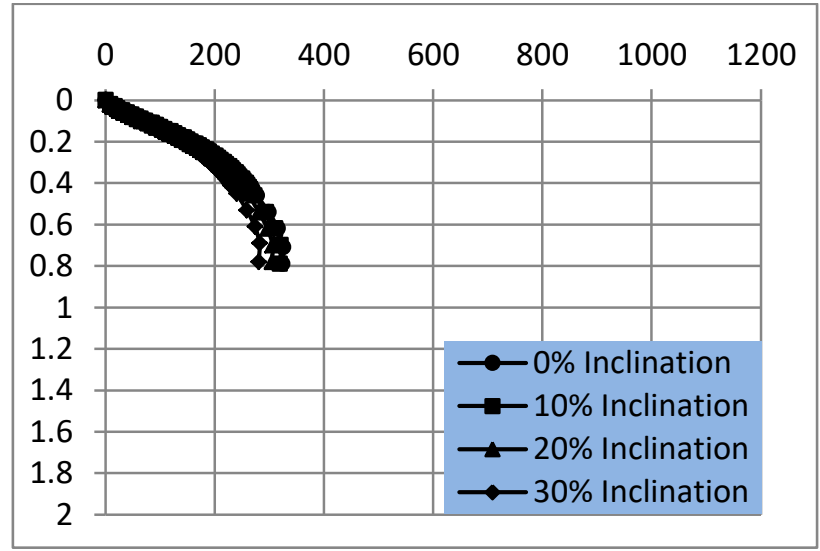

Fig. 34. Load-Settlement curve for a circular steel pile driven in dry sandy soil for bearing effect only



Fig. 35. Load-Settlement curve for a circular steel pile driven in dry sandy soil for shaft friction effect only

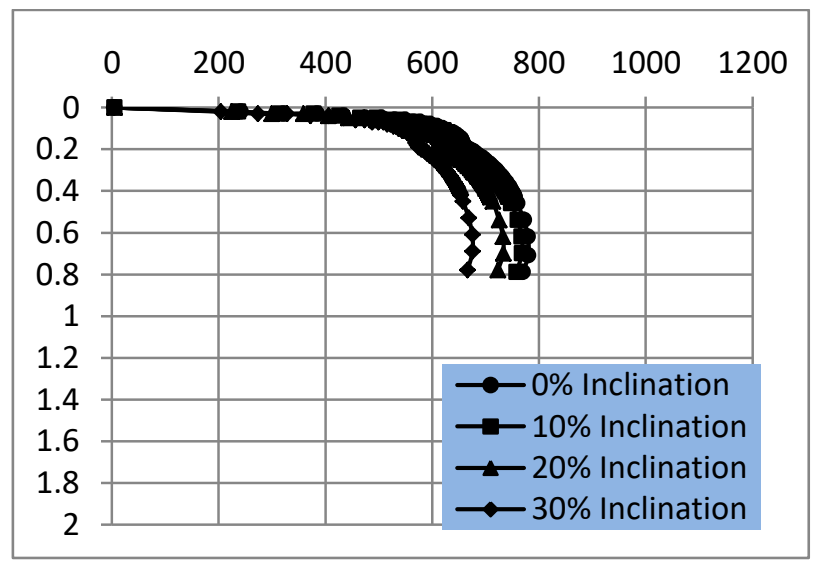

Fig. 36. Load-Settlement curve for a circular steel pile driven in dry sandy soil with different angles

\subsubsection{Driven hollow steel circular pile}

4 virtual model tests were performed in this type of piles with inclination $0,10,20$ and $30^{\circ}$. Figures (37) and (38) show the relation between load and settlement for bearing effect and friction effect only for pile, respectively. Figure (39) shows the relation between load and settlement. The loads corresponding 10\% settlement ratio are shown in Table (3).

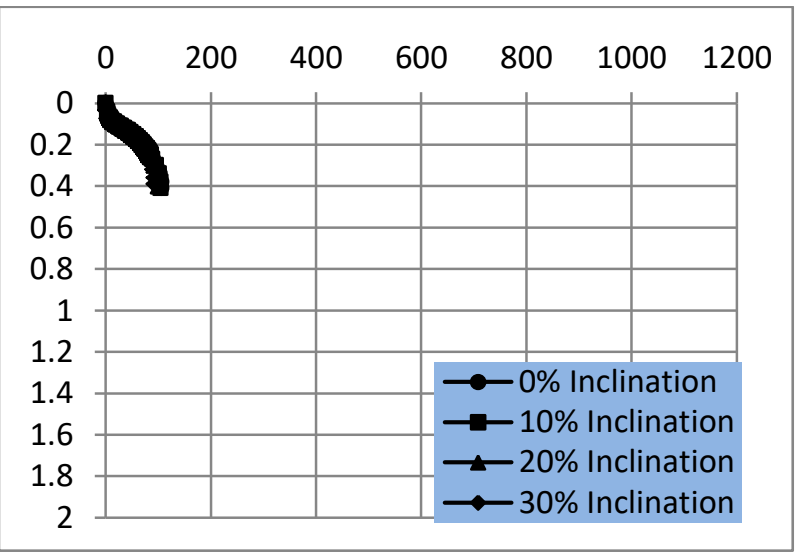

Fig. 37. Load-Settlement curve for a circular hollow steel pile driven in dry sandy soil for bearing effect only



Fig. 38. Load-Settlement curve for a circular hollow steel pile driven in dry sandy soil for shaft friction effect only

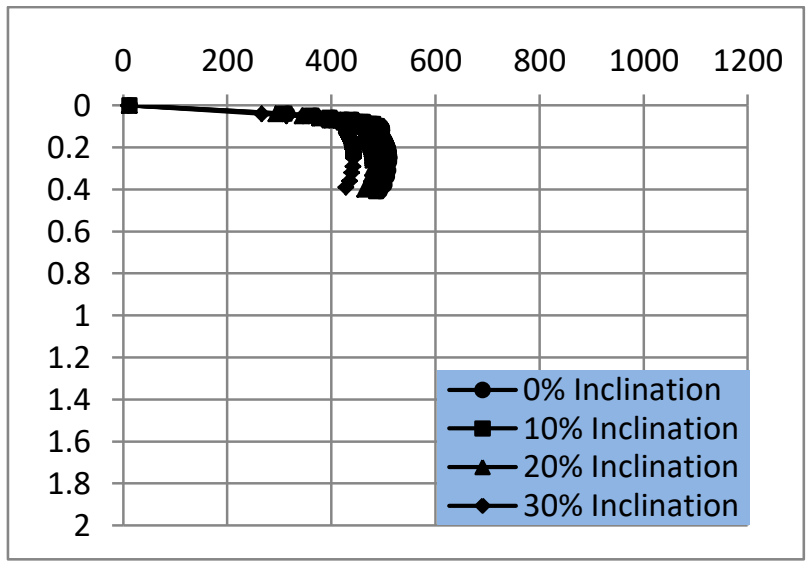

Fig. 39. Load-Settlement curve for a circular hollow steel pile driven in dry sandy soil 
Table 3. Summary of test results.

\begin{tabular}{|c|c|c|c|c|}
\hline Pile Type & Type & $\begin{array}{l}\text { Soft } \\
\text { Clay }\end{array}$ & $\begin{array}{c}\text { Fully Saturated } \\
\text { Sand }\end{array}$ & $\begin{array}{l}\text { Dry } \\
\text { Sand }\end{array}$ \\
\hline \multirow{5}{*}{$\begin{array}{c}\text { Square } \\
\text { Concrete }\end{array}$} & $\overline{\text { Angle }}$ & & & \\
\hline & $0^{\circ}$ & $250 \mathrm{kN}$ & 495 & 1100 \\
\hline & 10 & 240 & 488 & 1080 \\
\hline & 20 & 226 & 462 & 1040 \\
\hline & 30 & 212 & 435 & 940 \\
\hline \multirow{4}{*}{$\begin{array}{l}\text { Circular } \\
\text { Concrete }\end{array}$} & 0 & 192 & 423 & 846 \\
\hline & 10 & 186 & 392 & 825 \\
\hline & 20 & 180 & 372 & 800 \\
\hline & 30 & 165 & 344 & 744 \\
\hline \multirow{4}{*}{ Circular Steel } & 0 & 195 & 352 & 758 \\
\hline & 10 & 189 & 345 & 736 \\
\hline & 20 & 177 & 336 & 704 \\
\hline & 30 & 162 & 304 & 645 \\
\hline \multirow{4}{*}{$\begin{array}{c}\text { Circular } \\
\text { Hollow Steel }\end{array}$} & 0 & 177 & 230 & 486 \\
\hline & 10 & 170 & 225 & 474 \\
\hline & 20 & 162 & 215 & 460 \\
\hline & 30 & 150 & 197 & 420 \\
\hline
\end{tabular}

\section{Conclusions}

- The reduction ratio in failure load for the piles driven in soft clay soil are between $15-16 \%$ when the inclination increases from $0^{\circ}$ to $30^{\circ}$.

- The reduction ratio in failure load for the piles driven in fully saturated sandy soil are between $13-19 \%$ when the inclination increases from $0^{\circ}$ to $30^{\circ}$.

- The reduction ratio in failure load for the piles driven in dry sandy soil are between $13-15 \%$ when the inclination increases from $0^{\circ}$ to $30^{\circ}$.

- Type of soil is the main effect on bearing capacity of piles and the degree of saturation of sand is plays an important role on bearing capacity but did not effect on clayey soil according to Tomlison's equation for piles in clayey soils.

- Shaft resistance is more effective than bearing resistance for clayey and sandy soils and all types of pile because of dimensions and depth of piles.

\section{References}

1. R. Salgado, 1st ed. Mc Graw-Hill book company, New York (2006).

2. L. Li, S. Luo, ICTE 2011, pp. 1643-1648 (2011).

3. G. Mylonakis, A. Nikolaou, G. Gazetas Earthquake Engineering and Structural Dynamics (1997).

4. G. Gazetas, G. Mylonakis, Geotechnical Earthquake Engineering and Soil Dynamics III, ASCE, Geotechnical Special Publication (1998).

5. M. Sadek, I. Shahrour, Soil Dynamics and Earthquake Engineering (2004).

6. AllPile manual, version 7, 1 and 2, USA, (2014). 